\title{
Molecular identification and screening of mushrooms for antibacterial property against Pseudomonas aeruginosa and Staphylococcus aureus
}

\section{Mariselvi}

Department of Agricultural Microbiology, University of Agricultural Sciences, GKVK campus, Bangalore-560065 (Karnataka), India

\section{N. Earanna*}

Department of Agricultural Microbiology, University of Agricultural Sciences, GKVK campus, Bangalore-560065 (Karnataka), India

${ }^{*}$ Corresponding author. E-mail: earanna7@gmail.com

\begin{abstract}
In this study, 18 mushrooms were collected from Gandhi Krishi Vigyana Kendra (GKVK) campus, University of Agricultural Sciences, Bangalore (India) and identified by Internal Transcribed Spacer (ITS) region using National Centre for Biotechnology Information (NCBI) data base and screened for antibacterial property against two skin infection causing bacteria viz.,Pseudomonas aeruginosa and Staphylococcus aureus in dogs. Eleven mushrooms extract inhibited both the bacteria showing their antimicrobials as broad spectrum while inhibiting gram positive as well as gram negative bacteria. The highest zone of inhibition was recorded from the extract of Lyophyllum sp. The extract of two mushrooms viz., Phlebopus portentosus and Termitomyces sp. inhibited only $P$. aeruginosa, a gram negative bacterium and the extract of three mushrooms viz., Agaricus sp, Coprinellus disseminates and Agaricus blazei inhibited only S. aureus, a gram positive bacterium, suggesting spectral specificity of their antimicrobial compounds. However, the extracts of two mushrooms viz., Macrocybe gigantea and Schizophyllum commune did not show inhibition of any of the pathogens. Hence, this study suggests that the occurrence of potential pharmaceuticals in mushrooms can be exploited for control of multidrug resistant bacteria.
\end{abstract}

Keywords: Antibacterial activity, ITS region, Mushrooms, $P$. aeruginosa, S. aureus

\section{Article Info}

DOI: 10.31018/jans.v10i2.1682

Received: March 1, 2018

Revised: April 20, 2018

Accepted: May 18, 2018

\section{How to Cite}

Mariselvi, M. and Earanna, N. (2018). Molecular Identification and Screening of Mushrooms for Antibacterial property against $\mathrm{Pseu}$ domonas aeruginosa and Staphylococcus aureus. Journal of Applied and Natural Science, 10(2): 791- 796

\section{INTRODUCTION}

Mushrooms are macro-fungi with a distinctive fruiting body, that can be either hypogeous or epigeous, large enough to be seen by the naked eye and to be picked up by hand (Chang and Miles, 1992). Mushrooms produce antibacterial and antifungal compounds to survive in their natural environment. It is therefore not surprising that antimicrobial compounds with more or less strong activities could be isolated from mycelia or fruiting body which are useful for human health (Lindequist et al., 1990). Mushrooms are superior nutritional supplement but attributed with magnificent medicinal values too. The bioactive compounds present in mushroom includes, polysaccharides, lipopolysaccharides, proteins, peptides, glycoproteins, nucleosides, triterpenoids, lectins, lipids and their derivatives (Sharma et al., 2014). Fruiting bodies, mycelia, and spores accumulate a variety of bioactive metabolites with immunomodulatory, cardiovascular, liver protective, antifibrotic, anti-inflammatory, antidiabetic, antiviral, antioxidant, antitumor, and antimicrobial properties.
Staphylococcus aureus is a Gram-positive coccus that are commonly found on the skin of most mammals. These bacteria are able to produce and secrete numerous cell products that cause severe tissue damage. Staphylococci are also particularly adept at avoiding the effects of antibiotics. In particular, methicillin-resistant Staphylococci have emerged as a serious medical problem and they are able to develop and transfer resistance to numerous antibiotics by means of several divergent mechanisms (Upadhyay, 2011)

Pseudomonas aeruginosa is an opportunistic Gram negative pathogen of both human and veterinary species. This bacterium almost never affects healthy tissue but prefers damaged or diseased regions of the skin. In dogs, Pseudomonas otitis is the principal disease process caused by this organism. It is likely that the chronic alterations in the otic microenvironment associated with persistent inflammation, sets up a state of hyperhidrosis. The unique pathogenicity of Pseudomonas allows it to take advantage of the diseased tissue and develop resistance to antibiotics (Cholley et 
al., 2010).

The drug resistant patterns of the pathogens in community health settings are worrisome as most of these resistant bacteria are capable of horizontal gene transfer, decreased cell permeability against conventional antibiotics, and alteration of the ribosomal binding site (Adwan et al., 2014). Thus, the problem of antibiotic resistance is now become a global challenge in both under developed and developing countries (Levy, 2002; Sosa et al., 2010). The bacterial pathogens, P. aeruginosa and $S$. aureus are causing skin infection in animals and they are posing resistant to chemically synthesized antibiotics. In order to curb the problem of antibiotic resistances, the use of biologically active compounds originated from plants and fungi are necessary. The health-promoting benefits of secondary metabolites sourced from medicinal mushrooms had tremendously increased and the chances of obtaining novel and safe antimicrobial compounds, which would combat and reduce the incidence of antibiotic resistance (Alves et.al., 2012). Therefore, we attempted to explore the antibacterial mushrooms against Pseudomonas aeruginosa and Staphylococcus aureus.

\section{MATERIALS AND METHODS}

Molecular identification using ITS region sequence: During rainy season (July-September 2016), fruiting bodies of 18 wild mushrooms were collected from different locations at GKVK (Gandhi Krishi Vigyana Kendra) campus, University of Agricultural Sciences, Bengaluru-560065. The genomic DNA was extracted from tissue by modified CTAB (Cetyl Trimethyl Ammonium Bromide) lysis method (Doyle and Doyle, 1987). Fruiting body $(0.1 \mathrm{~g})$ was ground with extraction buffer $(1.5 \mathrm{ml})$ containing $\mathrm{CTAB}$, mixed with PVP and $B$ mercapto ethanol and incubated at $65^{\circ} \mathrm{C}$ for 45 minutes. Half of the sample was transferred into a new tube and equal volume of chloroform: isoamyl alcohol (24:1) was added. They were centrifuged at $10,000 \mathrm{rpm}$ for 10 minutes and the supernatant was transferred into a new tube. The DNA was precipitated by adding $600 \mu \mathrm{l}$ of chilled isopropanol and centrifuged at 10,000 rpm after overnight incubation. The pellet was washed with of $70 \%$ chilled ethanol, air dried and dissolved in 20-25 $\mu \mathrm{l}$ of double distilled water. The Ribo Nucleic Acid (RNA) was removed by adding $5 \mu$ of RNase and incubated at $37{ }^{\circ} \mathrm{C}$ for one hour. The purity and concentration the DNA was checked at $260 \mathrm{~nm}$ using BioMATE 3S UV-Visible spectrophotometer (Thermo Fisher Scientific, USA).

Genomic DNA was PCR amplified using $40 \mu \mathrm{l}$ reaction mixture containing $4.0 \mu \mathrm{l} 10 \mathrm{x}$ Taq. Buffer, $4.0 \mu \mathrm{l} 10 \mathrm{mM}$ dNTP mixture, $2.0 \mu \mathrm{l}$ ITS Primers, $0.6 \mu \mathrm{l}$ Taq. DNA polymerase, $2.0 \mu \mathrm{l}$ Template DNA, $27.4 \mu \mathrm{l}$ sterile distilled water (Sambrook et al., 1989). The PCR was carried out in a thermal cycler programmed as follows. Initial denaturation at $94{ }^{\circ} \mathrm{C}$ for $4 \mathrm{~min} .35$ cycles of denaturation at 94 ${ }^{\circ} \mathrm{C}$ for $1 \mathrm{~min}$, annealing at $60{ }^{\circ} \mathrm{C}$ for 30 secs, extension at $72{ }^{\circ} \mathrm{C}$ for $1 \mathrm{~min}$ and final extension at $72{ }^{\circ} \mathrm{C}$ for $10 \mathrm{~min}$. The amplified products were separated by agarose gel $(1 \%)$ electrophoresis. Then the DNA was eluted from the agarose gel using gel extraction kit (Gene JET TM Gel Extraction Kit,Thermo Scientific) and the eluted DNA was got sequenced by Scigenom Labs Pvt. Ltd, India using ITS1 and ITS4 primers. Sequence results were analyzed with online software (http:// www.ncbi.nlm.nih.gov/BLAST) of National Centre for Biotechnology (NCBI) (Altschul et al., 1990).

Preparation of mushroom extract and screening for antibacterial property: One gram of fresh tissue from the fruiting body was washed, surface sterilized using 5\% Sodium hypochlorite solution and repeatedly washed with sterile water. The tissue was crushed in $5 \mathrm{ml}$ sterile water using pestle and mortar to obtain $20 \%$ aqueous extract $(1 \mathrm{~g}$ in $5 \mathrm{ml}$ ). The extract was centrifuged and supernatant was collected. The extract thus obtained was filter sterilized using $0.22 \mu$ membrane filters attached to sterile disposable syringes. The extracts were collected in sterile eppendorff tubes and stored at $-20^{\circ} \mathrm{C}$ (Blue star, CHF 100B). The sterile water was used as control. The two bacteria viz., $P$. aeruginosa and $S$. aureus isolated from dog's otitis infection and dermatitis (Fig.1) from the Institute of Animal Health and Veterinary Biologicals (IAH abd VB), Karnataka Veterinary, Animal and Fisheries Sciences University (KVAFSU), Bangalore-560024 were obtained and cultured on Brain Heart Infusion Agar and Mannitol Salt Agar respectively.

The bacterial lawn was prepared on solidified nutrient agar medium. Sterile filter paper discs (Whatman No. 42) of $5 \mathrm{~mm}$ diameter were dipped in $20 \%$ mushroom extracts and placed on the lawn of the test organisms. Three filter paper discs have been used for each mushroom extract. The filter paper disc dipped in sterile water was used as control on the lawn. These plates were incubated at $37{ }^{\circ} \mathrm{C}$. The observation for inhibition zone was recorded after 24 hours. The minimum inhibitory concentration was determined by using different concentrations.

\section{RESULTS AND DISCUSSION}

Molecular identification: Mushrooms can be identified by both phenotypic and molecular characters. The morphological characters alone used in the classification are time consuming and often inadequate for exact strain identification. Morphological characterization also needs basic knowledge on the structure or phenotypic characters of mushrooms (Arora, 1986). However, in recent years, the molecular approach by using 


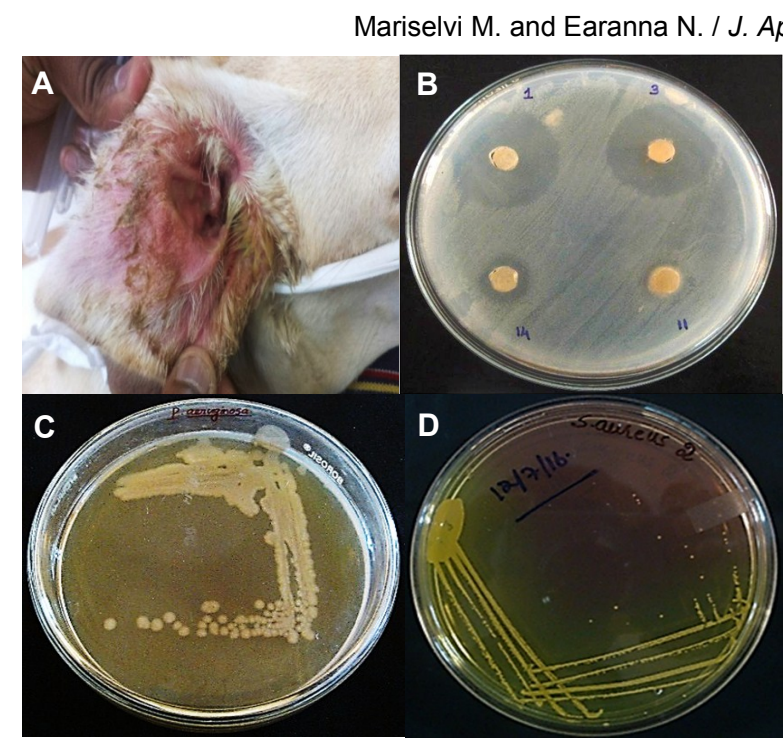

Fig.1.A. Dog's ear infection. B. Inhibition zone aused by mushroom extract $C$. Colonies of $P$. aeruginosa. $D$. Colonies of $S$. aureus.

Internal Transcribed Spacer (ITS) region/ 18S rRNA gene sequence are used for identification of mushrooms including other eukaryotes, as these sequences are conserved irrespective of life history and evolution (Rajaratnam and Thiagarajan, 2012). The internal transcribed spacer (ITS) region of the ribosomal DNA (rDNA) has been widely used for identification of mushrooms at both species and genus level (Sanchez-Ballesteros et al., 2000). The ITS region fragment ranges between 450 to 700 base pair has the highest probability of successful identification for the broadest range of fungi, with the most clearly defined gap

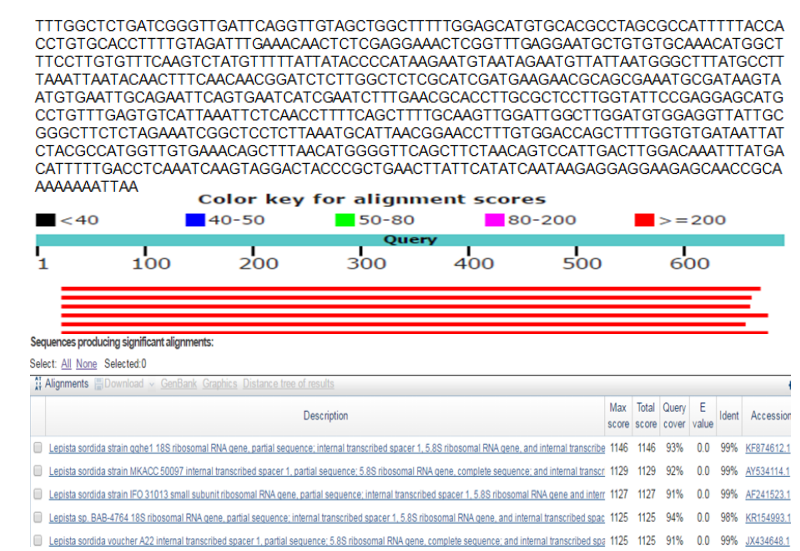

Fig.2. Partial sequence length and homology search of Lepista sordida (GKVK-1)

between inter- and intra-specific variation (Schoch et al., 2012). In the present study, eighteen mushrooms collected from different location of the campus were designated as GKVK-1, GKVK-2, GKVK3, GKVK-4, GKVK-5, GKVK-6, GKVK-7, GKVK-8, GKVK-9, GKVK-10, GKVK-11, GKVK-12, GKVK13, GKVK-14, GKVK-15, GKVK-16, GKVK-17 and GKVK-18 were identified up to species level by using ITS rRNA region sequence. The PCR amplification of genomic DNA of the eighteen mushrooms in the present study yielded amplified product size varying from 440 to $1054 \mathrm{bp}$ which are corresponding to almost full length gene sequence of ITS rRNA. The sequence homology of the eighteen species ranged from 87-99 per cent when aligned with the sequences present in NCBI (http://www.ncbi.nlm.nih.gov/BLAST) (Altschul et al., 1990). The mushroom designated as GKVK-1

Table 1. Effect of aqueous extract of mushrooms on $P$. aeruginosa and $S$. aureus.

\begin{tabular}{|c|c|c|}
\hline \multirow{2}{*}{ Mushrooms } & \multicolumn{2}{|c|}{ Diameter of inhibition zone $(\mathrm{mm})$} \\
\hline & $P$. aeruginosa & S. aureus \\
\hline Control (sterile water) & $0.00^{\dagger}$ & $0.00^{9}$ \\
\hline Lepista sordida & $7.33^{a}$ & $8.50^{\mathrm{a}}$ \\
\hline Lyophyllum sp. & $6.17^{\mathrm{de}}$ & $5.83^{\text {ef }}$ \\
\hline Psathyrella candolleana & $7.17^{\mathrm{ab}}$ & $7.50^{\mathrm{bc}}$ \\
\hline Lepiota sp. & $6.67^{\text {bcd }}$ & $6.50^{\text {def }}$ \\
\hline Macrocybe gigantea & $0.00^{f}$ & $0.00^{g}$ \\
\hline Agaricus xanthodermus & $6.17^{\text {de }}$ & $7.50^{\mathrm{bc}}$ \\
\hline Agaricus sp. & $6.17^{\text {de }}$ & $7.67^{\mathrm{ab}}$ \\
\hline Hymenagaricus sp. & $6.83^{\mathrm{abc}}$ & $6.17^{\text {ef }}$ \\
\hline Ganoderma multipileum & $7.33^{\mathrm{a}}$ & $6.67^{\text {cde }}$ \\
\hline Agaricus sp. & $0.00^{f}$ & $7.33^{\mathrm{bcd}}$ \\
\hline Schizophyllum commune & $0.00^{f}$ & $0.00^{g}$ \\
\hline Agrocybe pediades & $6.17^{\mathrm{de}}$ & $6.67^{\text {cde }}$ \\
\hline Phlebopus portentosus & $6.00^{\mathrm{e}}$ & $0.00^{9}$ \\
\hline Omphalotus olivascens & $6.33^{\text {cde }}$ & $7.17^{\mathrm{bcd}}$ \\
\hline Coprinellus disseminatus & $0.00^{f}$ & $7.33^{\mathrm{bcd}}$ \\
\hline Termitomyces sp. & $6.67^{\mathrm{bcd}}$ & $0.00^{g}$ \\
\hline Geastrum sp. & $6.33^{\text {cde }}$ & $6.50^{\text {def }}$ \\
\hline Agaricus blazei & $0.00^{f}$ & $5.67^{f}$ \\
\hline S. Em \pm & 0.187 & 0.296 \\
\hline LSD@5 \% & 0.536 & 0.848 \\
\hline
\end{tabular}

Means of the same superscript in a column do not differ significantly @ $\mathrm{P}=<0.05$ as per Duncan Multiple Range Test 


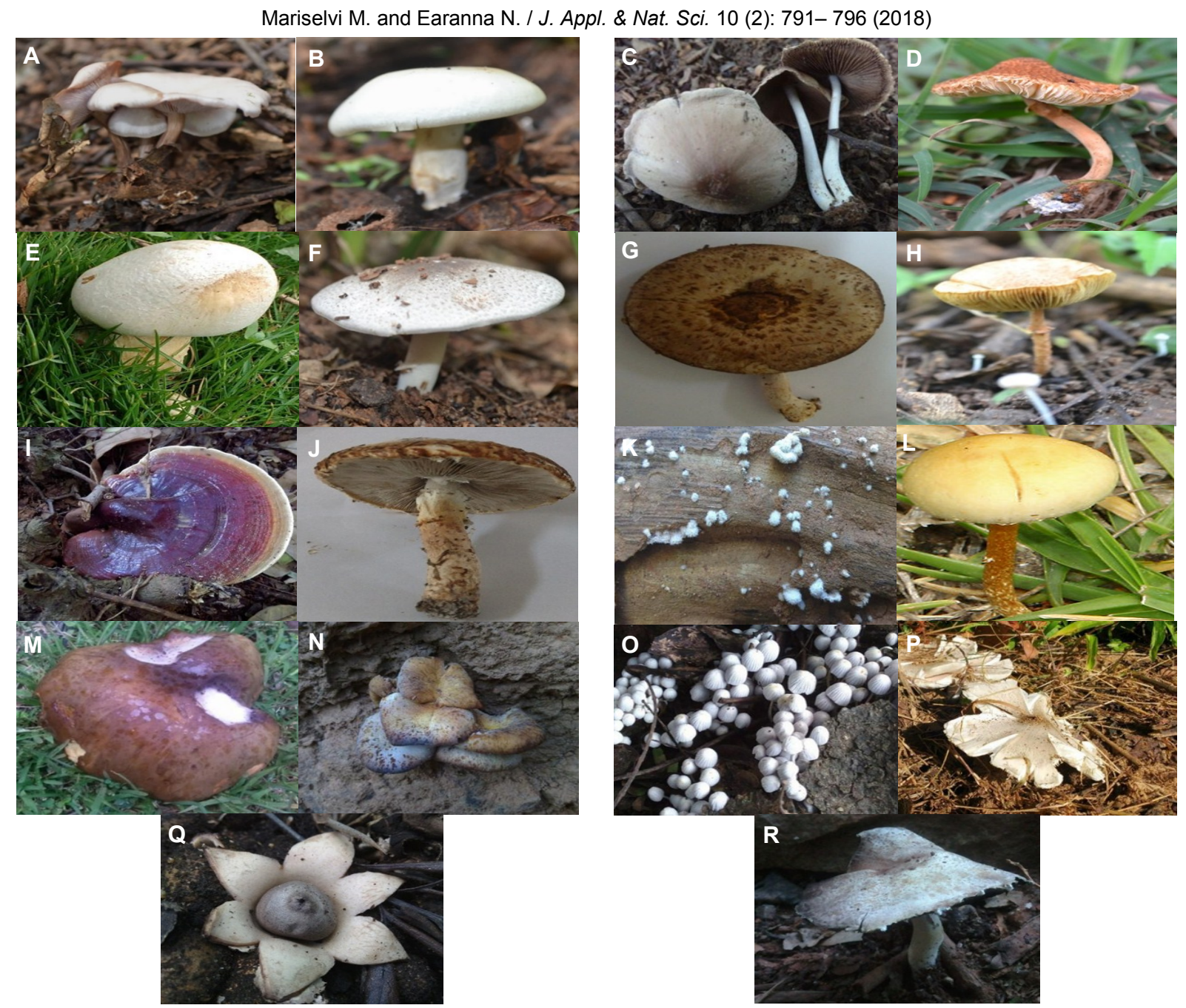

Fig. 3. Mushrooms identified and screened for antibacterial property. A- Lepista sordida, B- Lyophyllum sp., C- Psathyrella candolleana, D- Lepiota sp., E- Macrocybe gigantea, F- Agaricus xanthodermus, G- Agaricus sp., H- Hymenagaricus sp., I- Ganoderma multipileum, J-Agaricus sp., K- Schizophyllum commune, L- Agrocybe pediades, $M$ - Phlebopus portentosus, $\mathrm{N}$ - Omphalotus olivascens, $\mathrm{O}$ - Coprinellus disseminatus, P- Termitomyces sp., Q-Geastrum sp., R-Agaricus blazei

showed 99 percent homology to Lepista sordida (Fig.2), GKVK-2 with $98 \%$ to Lyophyllum sp., GKVK-3 with $95 \%$ to Psathyrella candolleana, GKVK-4 with $95 \%$ to Lepiota sp., GKVK-5 with $99 \%$ to Macrocybe gigantean, GKVK-6 with $97 \%$ to Agaricus xanthodermus, GKVK-7 with $99 \%$ to Agaricus sp., GKVK-8 with $87 \%$ to Hymenagaricus sp., GKVK-9 with $99 \%$ to Ganoderma multipileum, GKVK-10 with 95\% to Agaricus sp., GKVK11 with $98 \%$ to Schizophyllum commune, GKVK12 with $99 \%$ to Agrocybe pediades, GKVK-13 with $99 \%$ to Phlebopus portentosus, GKVK-14 with $99 \%$ to Omphalotus olivascens, GKVK-15 with $98 \%$ to Coprinellus disseminates, GKVK-16 with $98 \%$ to Termitomyces sp., GKVK-17 with $97 \%$ to Geastrum sp., and the GKVK-18 has $99 \%$ homology with Agaricus blazei (Fig.3, A-R, shows the fruit bodies of 18 identified mushrooms). Identification of mushrooms using ITS region sequence is advantageous as organism can be identified at any stages of the growth and it is widely used for identification several fungi (Schoch et. al., 2012). Raju et al. (2014) identified Volveriella species by PCR amplification of ITS region using ITS 1 and ITS 4 primers. Similarly, fourteen mushroom species including Termitomyces documented from Biligiri Rangana Hills of Westernghats of Karnataka were identified by ITS region sequence (Akash et al., 2017).

Effect of mushrooms extract on pathogens: Antimicrobial property of mushrooms due to the presence of antibiotics, tannins, alkaloids, flavonoids etc.(Draughon,2004). Out of eighteen wild mushroom extracts screened, eleven showed effective in inhibiting both the bacteria (Table,1). Significantly highest zone of inhibition was observed for Lepista sordida. The diameter of inhibition zone of this mushroom was $7.33 \mathrm{~mm}$ and $8.50 \mathrm{~mm}$ for $P$ aeruginosa and $S$ aureus respectively. The next best was the Psathyrella candolleana which caused $7.17 \mathrm{~mm}$ and $7.50 \mathrm{~mm}$ diameter of inhibition zone for $P$. aeuruginosa and $S$ 
Table 2. Minimum inhibitory concentration of mushroom extracts against $P$. aeruginosa

\begin{tabular}{lllllllllllllllllllll}
\hline \multirow{2}{*}{ Mushrooms } & \multicolumn{1}{l}{ Per cent concentration } & $\mathbf{2 0}$ & $\mathbf{1 8}$ & $\mathbf{1 6}$ & $\mathbf{1 4}$ & $\mathbf{1 2}$ & $\mathbf{1 0}$ & $\mathbf{8}$ & $\mathbf{6}$ & $\mathbf{4}$ & $\mathbf{2}$ & $\mathbf{1}$ & $\mathbf{0 . 8}$ & $\mathbf{0 . 6}$ & $\mathbf{0 . 4}$ & $\mathbf{0 . 2}$ & $\mathbf{0 . 0 9}$ \\
\hline & Lepista sordida & + & + & + & + & + & + & + & + & + & + & + & + & + & + & + & - \\
Lyophyllum sp. & + & + & + & - & - & - & - & - & - & - & - & - & - & - & - & - \\
Psathyrella candolleana & + & + & + & + & + & + & + & + & + & + & + & + & + & + & - & - \\
Lepiota sp. & + & + & + & + & + & + & + & + & + & + & + & + & + & - & - & - \\
Agaricus xanthodermus & + & + & + & + & + & + & + & + & + & + & + & + & + & - & - & - & - \\
Agaricus sp. & + & + & + & + & + & + & + & + & + & + & + & + & + & + & - & - \\
Hymenagaricus sp. & + & + & + & + & - & - & - & - & - & - & - & - & - & - & - & - \\
Ganoderma multipileum & + & + & + & + & + & + & + & + & + & - & - & - & - & - & - & - \\
Agaricus sp. & + & + & + & + & + & + & + & + & + & + & + & + & + & - & - & - \\
Agrocybe pediades & + & + & + & + & + & + & + & + & - & - & - & - & - & - & - & - \\
Omphalotus olivascens & + & + & + & + & + & + & + & + & + & - & - & - & - & - & - & - \\
Coprinellus disseminatus & + & + & + & + & + & + & + & + & + & + & + & + & + & - & - & - \\
Geastrum sp. & + & + & + & + & - & - & - & - & - & - & - & - & - & - & - & - \\
Agaricus blazei & + & + & + & - & - & - & - & - & - & - & - & - & - & - & - & - \\
\hline
\end{tabular}

$+=$ positive for inhibition zone; - = negative for inhibition zone

Table 3. Minimum inhibitory concentration of mushroom extracts on $S$. aureus.

\begin{tabular}{lllllllllllllllllll}
\hline \multirow{2}{*}{ Mushrooms } & \multicolumn{1}{l}{ Per cent concentration } & $\mathbf{1 0}$ & $\mathbf{2 0}$ & $\mathbf{1 8}$ & $\mathbf{1 6}$ & $\mathbf{1 4}$ & $\mathbf{1 2}$ & $\mathbf{1 0}$ & $\mathbf{8}$ & $\mathbf{6}$ & $\mathbf{4}$ & $\mathbf{2}$ & $\mathbf{1}$ & $\mathbf{0 . 8}$ & $\mathbf{0 . 6}$ & $\mathbf{0 . 4}$ & $\mathbf{0 . 2}$ \\
\hline Lepista sordida & + & + & + & + & + & + & + & + & + & + & + & + & - & - & - \\
Lyophyllum sp. & + & + & + & + & + & - & - & - & - & - & - & - & - & - & - \\
Psathyrella candolleana & + & + & + & + & + & + & + & + & + & + & + & + & + & + & - \\
Lepiota sp. & + & + & + & + & + & + & + & + & + & + & + & + & + & + & - \\
Agaricus xanthodermus & + & + & + & + & - & - & - & - & - & - & - & - & - & - & - & - \\
Agaricus sp. & + & + & + & - & - & - & - & - & - & - & - & - & - & - & - & - \\
Hymenagaricus sp. & + & + & + & + & + & + & + & + & - & - & - & - & - & - & - & - \\
Ganoderma multipileum & + & + & + & + & + & + & + & + & + & + & + & + & + & - & - \\
Agrocybe pediades & + & + & + & + & - & - & - & - & - & - & - & - & - & - & - \\
Phlebopus portentosus & + & + & + & - & - & - & - & - & - & - & - & - & - & - & - \\
Omphalotus olivascens & + & + & + & + & + & + & + & + & + & - & - & - & - & - & - \\
Termitomyces sp. & + & + & + & + & + & + & + & + & + & - & - & - & - & - & - \\
Geastrum sp. & + & + & + & - & - & - & - & - & - & - & - & - & - & - & - \\
\hline
\end{tabular}

$+=$ positive for inhibition zone: - = negative for inhibition zone

aureus respectively. Rest of the mushroom species showed varied inhibition zone for each pathogen. This indicates that these mushrooms in general contain antibacterial compounds that are probably broad spectrum ones and efficacy varied with mushroom species. The variations in the antimicrobial activities of mushrooms may be due to the differences in their bioactive compositions or concentrations, methods of extraction and mechanism of action of active ingredients present in these mushrooms (Iwalokun et al., 2007). Further, the extracts of two mushrooms (Phlebopus portentosus and Termitomyces sp.) inhibited only $P$. aeruginosa and three mushrooms viz., Agaraicus sp., Coprinellus disseminates and Agaricus blazei inhibited only $S$. aureus. This variation in antimicrobial activities of mushrooms may be due the differences in their bioactive compositions or concentrations, methods of extraction and mechanism of action of anti-ingredients in mushrooms (Iwalokun et al., 2007) as $P$. aeruginosa is a gram negative and $S$. aureus is a gram positive bacteria. Quang et al. (2006) reported that the benzoic acid derivative isolated from mushroom Xylaria intracoiarata showed antibacterial activity against only gram negative bacteria viz., Escherichia coli, Psiudomonas aeuroginosa and Solmonella enteritidis.

Two mushrooms viz., Macrocybe gigantea and Schizophyllum commune did not show any inhibition on either bacterium. These mushrooms might not have produce antibacterial against the targeted pathogens. Otherwise, method of extraction may also influence because, in earlier studies, ethanol extract of Ganoderma lucidum did not inhibit Staphylococcus aureus, Bacillus, Alcaligenes faecalis, and Proteus vulgaris but, benzene, chloroform, and ethyl acetate extracts gave better results on inhibition of test organisms (Shikongo et al. 2013). Beattie et al. (2010) also reported the efficacy of ethyl acetate extract of the mushrooms viz., Cortinarius ardesiacus, C. archeri, C. atrosanguineus, C. austrovenetus, C. austroviolaceus, C. coelopus, C. clelandii, C. memoria -annae, C. persplendidus, C. sinapicolor, C. vinosipes on inhibition of Staphylococcus aureus. The minimal inhibitory concentration (MIC) of mushrooms extract varied between two pathogens. MIC ranged between $0.2 \%$ to $16 \%$ for $P$. aeruginosa (Table,2, Fig.1B). Least concentration 
of $L$. sordida extract being 2 percent showed inhibition of $P$. aeruginosa indicating its potentiality at minimal concentration. Similarly, the extract of mushrooms $P$. candolleana and Lepiota sp. showed $0.4 \%$ as MIC against $S$. aureus (Table,3). This suggest that the antimicrobial present in different mushrooms and their mode of action may differ for different pathogen. Kolundzic and Marina (2016) reported that the antibacterial activity of aqueous extracts of tinder fungus Fomes fomentarius against Helicobacter pylori with MIC values between 4-30 $\mu \mathrm{g} / \mathrm{ml}$.

\section{Conclusion}

In our study, 16 mushroom species exhibited antibacterial activity against $P$. aeruginosa and $S$. aeurus. Though the inhibition pattern varied for different mushroom species, all 16 mushrooms can be exploited for isolation of pure compounds to use against multi drug resistant pathogens as only crude extracts were used in this study. Among 16 mushroom species, the $L$. sordida showed maximum inhibition zone against both bacteria. Therefore, $L$. sordida would be the best mushroom for antibacterial compounds compared to others. Further, $P$. portentosus and Termitomyces sp can be exploited for controlling gram negative bacteria as they specifically inhibited $P$. aeruginosa but not $S$ aureus. Similarly, Agaricus sp, Agaricus blazei and Coprinellus disseminates were more efficient against gram positive bacteria as they inhibited $S$. aureus alone.

\section{REFERENCES}

Adwan G. K., Naser J and Alaa A. (2014) Molecular detection of nine antibiotic resistance genes in methicillin resistant Staphylococcusaureus isolates. Rom. Arch. Microbiol. Immunol., 73 (1-2), 9-18

AkashD., Earanna, N and Subramanya, S., (2017) Mushroom diversity in the Biligiri Rangana hills of Karnataka (India)., J. Appl. Natl. Sci., 9, 1381-1387

Altschul S. F., Gish, W. and Lipman, W. W., (1990) Basic Local Alignment Search Tool. J. Mol. Biol.,215 (3), 403-410

Alves M., Ferreira I. F. R., Dias J., Teixeira V., Martins A. and Pintado M., (2012) A review on antimicrobial activity of mushroom (Basidiomycetes) extracts and isolated compounds. PlantaMed., 78(16), 1707-1718

Arora D., ,(1986) Mushroom demystified: A comprehensive guide to the fleshy fungi. Ten Speed Press, Crown Publishing Group, New York

Beattie, K. D., Rouf, R., Gander. L., May, T. W., Ratkowsky, D., Donner, C. D., Gill, M., Grice, I. D. and Tiralongo, E., (2010) Antibacterial metabolites from Australian macrofungi from the genus Cortinarius. Phytochem., 71: 948-955.

Chang S. T. and Miles P. G., (1992) Mushroom biologya new discipline. Mycologist,6, 64-65

Cholley, P., Gbaguidi-haore, H., Bertrand, X., Thouverez, M., Plesiat, P. and Hocquet, D., (2010) Molecular epidemiology of multidrug-resistant Pseudomonas aeruginosa in a French university hospital. J. Hospital
Infect., 76(4): 316-9.

Doyle J. J. and Doyle J. L., (1987) A rapid DNA isolation procedure for small quantities of fresh leaf tissue. Phytochemical Bulletin, 19, 11-15

Draughon F. A.,(2004) Use of botanicals as biopreservatives in foods. Food Technol.,58(2), 20-28

Iwalokun B. A., Usen U. A., Otunba A. A. and Olukoya, D. K., (2007) Comparative phytochemical evaluation, antimicrobial and antioxidant properties of Pleurotus ostreatus. Afri. J. Biotechnol.,6(15), 1732-1739

Kolundzic and Marina., (2016) Antibacterial and cytotoxic activities of wild mushroom Fomes fomentarius (L.) Fr., Polyporaceae. Ind. Crops Prod., 79, 110-115

Levy S. B., (2002) Factors impacting on the problem of antibiotic resistance. J. Antimicrob. Chemother., 49 (1), 25-30

Lindequist, U., Teuscher, E. and Scar, G., (1990) New substances from Basidiomycetes. Z. Phytother11, 139-49

Quang, D. N., Bach, D. D., Hashimoto, T. and Asakawa, Y., (2006) Chemical constituents of the Vietnamese inedible mushroom Xylaria intracolorata. Nat. Prod. Res., 20: 317- 321.

Rajaratnam S. and Thiagarajan T., (2012) Molecular characterization of wild mushroom. Eur. J. Exp. Bio,2 (2), 369-373

Raju R., Vasanthi V. J., Mathiyazhagan S., Nagarajan R., Amutha G. and Valazhahan R., (2014) Molecular characterization of Volvariella volvacea (Bull. Ex Fr.) Sing strain WV and analysis of variability among Gen Bank repositories based on ITS region of rDNA. Int. J. Curr. Microbiol. App. Sci.,3(5):487-492

Sambrook, J., Fritsch, F.F., and Maniatis,T. (1989) Molecular cloning: A laborataory manual, Cold Spring Harbor Laboratory Press, Cold Spring Harbor, Newyark,USA. Pp.931-957

Sanchez- Ballesteros, J., Gonzalez, V., Salazar, O., Acero, J., Portal, M. A., Julian, M., Rubio, V., BILLS, G. F., Polishook, J. D., Platas, G., Mochales, S. and Pelaez, F., (2000) Phylogenetic study of Hypoxylon and related genera based on ribosomal ITS sequences. Mycologia, 92(5): 964-977

Schoch, L. C., Seifert, K. A., Huhndorf, S., Robert, V., Spouge, J. L., Re Levesque, C.,Chen, W., Bolchacova, E., Voigt, K., Crous, P. W. and Miller, A. N. (2012) Nuclear ribosomal internal transcribed spacer (ITS) region as a universal DNA barcode marker for fungi. PNAS, 109(16): 6241-6246.

Sharma A. K., Jana A. M., Srivastav A., Gupta M., Sharma S. and Gill S. S., (2014) Antimicrobial properties of some edible mushrooms: A review. World J. Pharm. Pharm. Sci.,3(5), 1009-1023

Shikongo, L. T., Chimwamurombe, P. M., Lotfy, H. R. and Kandawa-Schulz, M., (2013) Antimicrobial screening of crude extracts from the indigenous Ganoderma lucidum mushrooms in Namibia. Afr. J. Microbiol. Res., 7(40): 4812-4816.

Sosa, A. J., Byarugaba, D. K., Amabile-cuevas, C. F., Hsueh, P. R., Kariuki, S. and Okeke, I. N., (2010) Antimicrobial Resistance in DevelopingCountries, Springer, New York, USA

Upadhyay, R. K., (2011) Emergence of drug resistance in microbes, its dissemination and target modification of antibiotics: a life threatening problem to human society. Int. J. Pharm. Biol. Res., 2(5): 119-126. 